А.М. Бондаренко, В.С. Копча

\title{
РОЗДУМИ СТОСОВНО ЛІКУВАЛЬНОЇ ТА ПРОФІЛАКТИЧНОЇ ПЕРСПЕКТИВНОСТІ РІЗНИХ ЗАСОБІВ ПРИ COVID-19
}

\author{
КП «Криворізька міська клінічна лікарня № 2» КМР, КП «Криворізький Центр здоров'я» КМР, \\ Тернопільський національний медичний університет імені І.Я. Горбачевського
}

Мета роботи - на підставі зіставлення особливостей попередніх епідемій коронавірусних інфекцій та аналізу патогістології, патогенезу COVID-19 і досвіду емпірично апробованого лікування таких хворих виділити перспективні напрямки подальших засобів терапії та профрілактики.

Наведено інфрормацію про зворотну залежність у ряді SARS $\rightarrow$ MERS $\rightarrow$ COVID-19 географрічної поширеності з інкубаційним періодом і летальністю.

У патогенезі COVID-19 виділено два основні патогенетичні механізми: пряме вірусне пошкодження епітелію легень, ендотеліоцитів капілярів і тканинних легеневих фрібробластів, а також прогресуюча запальна реакція, що супроводжується «цитокіновою бурею», яка спочатку може призводити до «гострого респіраторного дистрес-синдрому» (ГРДС), а потім - й до так званого синдрому гострої запальної відповіді. Таким чином, патогенез COVID-19 схожий з грипозними «геморагічними пневмоніями» або грипозним геморагічним набряком легень. Це дає змогу припускати першорядне значення не етіотропної, а патогенетичної протинабрякової, протизапальної та ангіопротекторної терапії хворих на COVID-19.

Перспективними профрілактичними стосовно COVID-19 засобами видаються готові інтерферони або індуктори інтерфероногенезу.

Ключові слова: COVID-19, епідеміологія, патогістологія, патогенез, лікування, профрілактика.

Вже утретє за останні 20 років у світі виникають розповсюджені епідемії коронавірусних інфекцій, що характеризуються високою контагіозністю і високим рівнем летальності. Усі вони були спричинені вірусами одного й того ж типу - бета-коронавірусами (родина Coronaviridae, підродина Coronavirinae, рід Betacoronavirus).

У 2002 р. це була епідемія SARS (від англ. «Severe Acute Respiratory Syndrome») або тяжкий гострий pecпіраторний синдром, спричинений вірусом SARS-CoV-1 (підрід В бета-коронавірусів), у 2012-2015 рр. - епідемія MERS (від англ. «Middle East Respiratory Syndrome») або Близькосхідний респіраторний синдром, зумовлений MERS-CoV (підрід C бета-коронавірусів), і вже в 2019 р. пандемія COVID-19, спричинена вірусом SARS-CoV-2.

Відразу зазначимо, що усі три іноекції - зооантропонози (резервуаром і джерелом збудника є тварини, а саме рукокрилі, для MERS - одногорбі верблюди, яким раніше вірус був переданий від рукокрилих, а в людській популяції власне хворі на коронавірусну інфекцію).

Первинним географрічним місцем виникнення був азіатський регіон: для SARS - Південний Китай; для MERS - Саудівська Аравія; для COVID-19 - Центральний Китай. Також можна говорити і про періодичність виникнення коронавірусних епідемій в людській популяції, яка становить близько 7-10 років. Варто звернути увагу на зворотну залежність у ряді SARS $\rightarrow$ MERS $\rightarrow$ COVID-19 географічної поширеності 3 інкубаційним періодом і летальністю.

Так, найбільше розповсюдження SARS було в країнах Південно-Східної Азії (Китай, Гонконг, Тайвань, Сінгапур, В'єтнам) і в Північній Америці (США, Канада). Всього, за даними ВОО3, було зареєстровано 8098 випадків хвороби. Механізм передачі - аерозольний і фекально-оральний. SARS мав короткий інкубаційний період - 2-3 доби. Летальність при цій недузі становила близько 9-10 \% (9,55 \%).

MERS був зареєстрований в 27 країнах і був в основному обмежений Близьким Сходом (Алжір, Бахрейн, Єгипет, Китай, Австрія, Франція, Німеччина, Греція, Ісламська Республіка Іран, Італія, Йорданія, Кувейт, Ліван, Малайзія, Нідерланди, Оман, Філіппіни, Катар, Республіка Корея, Королівство Саудівська Аравія, Таїланд, Туніс, Туреччина, Об'єднані Арабські Емірати, Сполучене Королівство, Сполучені Штати Америки і Йемен). 80 \% хворих було зосереджено в місці виникнення - Саудівській Аравії. Передача MERS від людини до людини відбувається тільки при тісному контакті, але основним джерелом все жє верблюди. Всього у світі було зареєст- 
ровано 2144 випадки хвороби. Механізм і шляхи передачі інфекції до кінця не вивчені. Хоча основним все ж $€$ аерозольний (від людини людині). Шляхи передачі повітряно-краплинний, контактно-побутовий. Інкубаційний період при MERS становив близько 5 діб. Летальність при MERS досягала $35 \%$.

COVID-19 - сучасна поточна пандемія з більш ніж 10000000 хворих. Механізми передачі збудника - aерозольний і фрекально-оральний. Шляхи передачі - повітряно-краплинний, аліментарний, контактно-побутовий. Інкубаційний період може подовжуватися до 14 діб. Летальність при COVID-19 на сьогодні коливається від 1,5 до $5,5 \%$.

Таким чином, у ряді SARS $\rightarrow$ MERS $\rightarrow$ COVID-19 відзначається збільшення поширеності від епідемії до пандемії, підвищення контагіозності, але зі збільшенням інкубаційного періоду, і все-таки, зниженням рівня летальності.

3 доступних інформаційних джерел відомо, що в патогенезі COVID-19 можна виділити два основні механізми ушкодження легень. Перший - це пряме вірусне пошкодження епітелію легень, передусім гладких епітеліальних клітин дихальних шляхів і альвеолоцитів, а також ендотеліоцитів капілярів і тканинних легеневих фрібробластів, оскільки коронавіруси після закінчення реплікації призводять до повного пошкодження клітини хазяїна. Другий - виникнення спочатку інтенсивної локальної (легені), а потім вже й системної запальної реакції, що супроводжується «цитокіновою бурею». Це зрештою при тяжкому ступеню хвороби спочатку призводить до «гострого респіраторного дистрес-синдрому» (ГРДС) [1], а потім, при прогресуванні хвороби, - й до так званого синдрому гострої запальної відповіді (SIRS від англ. Systemic Inflammatory Response Syndrome). У вітчизняних джерелах це ототожнюється із сепсисом, хоча фрактично таким у жодному разі не $є$, оскільки віруси не можуть бути збудниками сепсису!

Слід зазначити, що SARS-CoV-2 тропний до ангіотензинперетворювального фермента (ACE2 ) - екзопептидази, що проявляє протеазну активність на поверхні ендотеліальних клітин капілярів легень. 3 еволюційного погляду предки сучасних коронавірусів взаємодіяли з цими рецепторами на поверхні найпростіших і пептидазаза розщепляла їх оболонку, завдяки чому вірусна РНК проникала в клітину і запускала механізм свого розмноження. У міру ускладнення багатоклітинних форм життя ця екзопептидаза стала брати участь у перетворенні ангіотензину I на судинозвужувальну речовину ангіотензин II за тим же механізмом протеолітичного розщеплення, регулюючи у нас артеріальний тиск. Тож SARS-CoV-2, як і його предки, взаємодіє саме з цими рецепторами. У такий спосіб цей вірус вільно реплікується в альвеолоцитах (в окремих повідомленнях вказують саме на 2-й тип альвеолоцитів), ендотелії капілярів, легеневих фрібробластах і ентероцитах - структурах, які містять найбільшу кількість АCE2.

Коронавіруси дуже складно вдається «вирощувати» в культурах клітин in vitro. Але 3 публікацій стосовно SARS i MERS відомо, що ці віруси вже в найближчі години після інфрікування, а саме через 7-13 год, накопичуються в клітині-хазяїні у високих концентраціях, досягаючи піку через 12-24 год і, зберігаючись на високому рівні, призводять до чіткої цитопатичної дії та загибелі клітин. Час від інфрікування клітини до її загибелі залежить власне від типу і навіть штаму коронавірусу, а також від культури клітин і становить від 12-24 год до 7-14 діб. Найесрективніша реплікація коронавірусів при SARS i MERS відбувається в гладких епітеліальних клітинах дихальних шляхів, гірше збудники реплікуються в тканинних фрібробластах, далі за зниженням активності реплікації йдуть пневмоцити 2-го порядку і найнижчий рівень реплікації відзначається в ендотеліоцитах [2].

Згадані пневмоцити типу II (АТ2) відповідальні за утворення легеневого сурфрактанту - суміші ліпідів і білків, що вистилає легеневі альвеоли зсередини (на межі «повітря-рідина»). Легеневий сурфрактант перешкоджає злипанню стінок альвеол при диханні за рахунок зниження поверхневого натягу плівки тканинної рідини, що покриває альвеолярний епітелій [3].

SARS-CoV-2, інфікувавши пневмоцити, спричиняє їх десквамацію в альвеолах, сприяючи альвеолярній диссрункції, набряку і кровотечі, що порушує газообмін в альвеолах і призводить до дихальної недостатності. Одночасно відбувається зниження рівня сурфактанту в тканинній рідині, що покриває альвеолярний епітелій, її поверхневий натяг збільшується. Відповідно, здатність легень розширюватися і стискатися під час нормального акту дихання знижується (пацієнт цей стан відчуває як «хрускіт легень» при кожному вдиху). Цей процес може призвести до колапсу легень під час видиху. У міру заповнення альвеол рідиною наростає дихальна недостатність. Смертельний вислід настає при порушенні цілісності альвеолярної мембрани, що призводить до накопичення рідких ексудатів у альвеолярних просторах, механічна вентиляція легень виявляється безуспішною [3].

Важливо, що прогресування ГРДС від набряку альвеол до дифузного альвеолярного пошкодження (diffuse alveolar damage) не залежить від інтенсивності реплікації вірусу і досягнення ним високих титрів. Інфекція призводить до пікових вірусних титрів через 1-2 доби після зараження, разом з оголенням (денудацією) дихальних шляхів і утворенням клітинного детриту, що закупорює дрібні бронхи (одна з причин, що ускладнює 


\section{ОГЛЯДИ ТА ЛЕКЦІї}

виявлення вірусу у верхніх дихальних шляхах). Тяжкі ураження паренхіми легень, у тому числі інфрільтрати, крововиливи, альвеолярний набряк і утворення гіалінової мембрани, типові для ексудативної стадії дисузного альвеолярного пошкодження, з'являються на 4-7-у добу після зараження, коли вірусне навантаження в паренхімі легень швидко падає і/або стає нижче межі виявлення [3].

На жаль, через небезпеку зараження, багатьох померлих від COVID-19 в Україні взагалі не розтинали, пізніше секцію здійснювали, але нерідко без виконання повноцінних гістологічних досліджень, хоча патогістологічний матеріал забирали і зберігали.

Патогістологічне дослідження легень померлих від COVID-19 дозволяє виявити у просвіті альвеол велику кількість білкового ексудату з гранулами, великі організовані білкові глобули, внутрішньоальвеолярний фрібрин з ранньою організацією, а також гіперпластичні пневмоцити 3, можливо, вірусними включеннями. Також на мікрофротографріях помітні вільні еритроцити у просвіті альвеол, чіткі деструктивні зміни в їх структурі, має місце еритроцитарна і лейкоцитарна інорільтрація інтерстицію [4] (фрото 1).

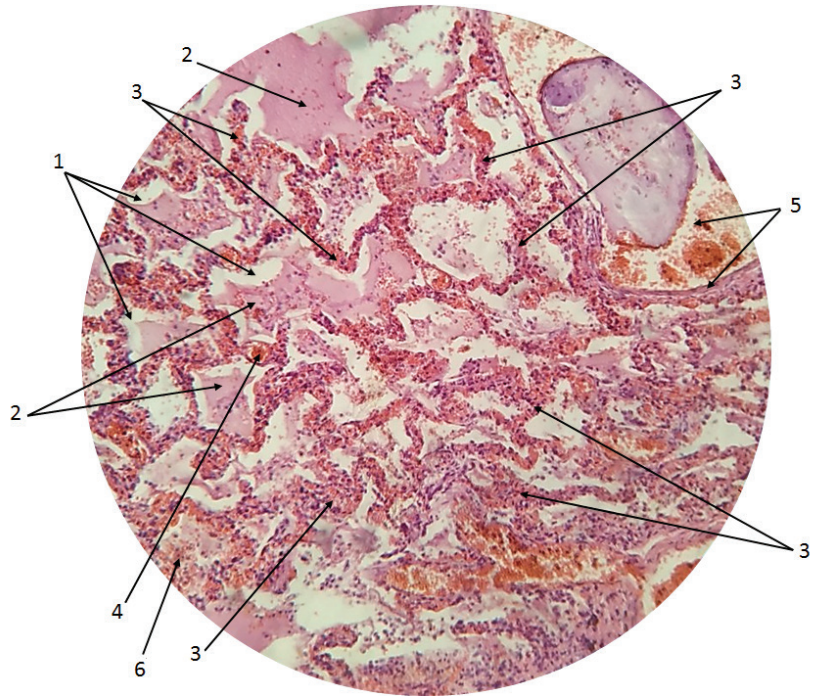

Фото 1 (належить авторам статті). Гістологічний препарат легені хворої, яка загинула від COVID-19:

1 - десормовані альвеоли;

2 - гіалінові мембрани у просвіті альвеол (організовані маси фрібрину, клітинний детрит, еритроцити, лейкоцити);

3 - потовщені, десрормовані, інфрільтровані еритроцитами і лейкоцитами альвеолярні стінки та міжальвеолярні перегородки;

4 - розширений легеневий капіляр;

5 - бронх (у просвіті згусток слизу і скупчення еритроцитів);

6 - скупчення еритроцитів у просвіті альвеол.
Аналіз гістологічної картини достовірно ілюструє те, що у таких хворих має місце інтерстиційний та альвеолярний геморагічний набряк легень, що розпочинається. Тому, використовуючи наведене дослідження, можна ще раз підтвердити те, що SARS-CoV-2 тропний до альвеолоцитів 1-го і 2-го порядку, тканинних фрібробластів і макрофрагів, а також до ендотелію судин. Непрямим підтвердженням цьому можуть бути й дані патогістологічної картини при SARS і MERS.

Таким чином, стає очевидним, що в патогенезі COVID-19 при тяжкому ступеню хвороби чітко простежується наступна етапність або стадійність. Після інфікування альвеолоцитів, ендотеліоцитів альвеолярнокапілярного сегменту легень, тканинних фрібробластів і макрофрагів через недовгий проміжок часу (12-24-48 або 72 год) в цих клітинах (більше в пневмоцитах) виникає виражений цитопатичний ефект, який призводить до швидкого прогресу спочатку інтерстиційного набряку легень, а потім і альвеолярного набряку, який спочатку супроводжується пропотіванням в альвеоли плазми крові, а потім вже й фрормених елементів. Природно, що вже на перших етапах пошкодження альвеолярно-капілярного сегменту швидко призводить до прогресуючого погіршення газообміну, а також закономірно супроводжується вираженою локальною, а потім і системною запальною реакцією. Важливо, що швидке пошкодження пневмоцитів і структури альвеолярно-капілярного сегменту не може бути компенсоване використанням штучної вентиляції легень (ШВЛ), навіть з високим вмістом кисню в дихальній суміші і підвищеним тиском при ШВЛ на видиху. На жаль, у цьому ми продовжуємо переконуватися практично щоденно.

Наведені дані ілюструють дуже високу схожість патогенезів SARS, MERS i COVID-19 з грипозними «геморагічними пневмоніями» або грипозним геморагічним набряком легень, який також закономірно (за відсутності адекватної терапії) має два етапи у вигляді інтерстиційного, а потім вже й альвеолярного геморагічного набряку. Клініко-діагностичний і терапевтичний алгоритм при грипозному геморагічному набряку легень, наведений в патентах і статтях [5-8], теоретично може з успіхом використовуватися і при COVID-19.

Нині етіотропна терапія COVID-19 (SARS-CoV-2) не розроблена. Проте, теперішні повідомлення засвідчують ефективність і можливість застосування в терапії COVID-19 фрармакологічних засобів різних груп, у тому числі й дуже далеких від групи противірусних препаратів. Деякі з них вже навіть включені в різні національні керівництва з лікування COVID-19.

Із групи противірусних препаратів з різним механізмом дії можна навести наступні: інгібітори вірусних полімераз (аналоги нуклеозидів і нуклеотидів) - рибавірин 
(Ribavirin), фравіпіравір (Favipiravir), фравілавір (Favilavir) і ремдесивір (Remdesivir); інгібітори вірусних протеаз лопінавір+ритонавір (Lopinavirum+Ritonavirum); інгібітори злиття - арбідол (Arbidol); інтерферони (ІФН), у тому числі й пролонговані (ІФН- $\alpha 2 \mathrm{a}$ (Pegasys), ІФН- $\alpha 2 \mathrm{~b}$ (Pegintron)), 3 акцентом на вищу ефективність $\beta-І Ф Н$ (ІФН-ß1a (Avonex, Rebif, Genfaxon, CinnoVex та ІФН- $\beta 1 \mathrm{~b}$ (Betaseron)). Вже навіть описані практично використовувані три- і двокомпонентні схеми терапії таких хворих.

Щоправда застосування наведених засобів має істотні обмеження, коли очікуваний ефект і користь від використання у хворого суттєво поступаються ризику такої терапії, безпосередньо пов'язаної із загальновідомими побічними ефектами (токсичність) і ускладненнями. Наприклад, сьогодні утримуються від застосування ще донедавна популярних похідних 4-амінохіноліну (протималярійних гематошизотропних препаратів) хлорохіну (делагіл (Delagil)) і гідроксихлорохіну (гідроксихлорохін (Hydroxychloroquine), плаквеніл (Plaquenil), іммард (Immard) та ін.), оскільки, поряд з цілковитим позбавленням доказової бази, доведено достовірно вищу смертність у групі хворих, які їх отримували, порівняно з особами, лікованими за допомогою тільки патогенетичних і симптоматичних базисних засобів.

Дуже багато сподівань покладалося на згаданий вже ремдесивір (включений до протоколу лікування COVID-19 в Україні), який, за даними американської компанії-розробника «Gilead Sciences», має найбільші шанси показати позитивний результат у короткостроковій перспективі. Втім розробники довели, що цей лікарський засіб дозволяє пришвидшити одужання всього на 4 доби, а от зниження смертності виявилося дуже скромним - 8 \% проти 11,6 \% у контрольній групі, що фрактично перебуває на межі статистичної похибки. Попри це, управління продовольства і медикаментів США надало дозвіл для екстреного використання «Ремдесивіру». Та ейсрорія щодо нього доволі швидко вщухла, адже китайські дослідники, провівши у квітні ц.р. масштабне плацебоконтрольоване дослідження, встановили, що цей засіб практично ніяк не допомагає лікувати хворих на COVID-19. За їх даними, найважливіший параметр смертність серед тих, хто його приймав, статистично не відрізнялася порівняно з контрольною групою. А згаданий дозвіл такого престижного управління більше схожий на психологічний крок, щоб заспокоїти суспільство і дати йому знак, що, мовляв, успіхи вже є.

Важливо, що досвід застосування противірусної терапії при гострих вірусних інфекціях (наприклад, грипі), особливо тяжкого ступеня, неодноразово підтверджував її ефрективність тільки на ранніх етапах розвитку недуги, а саме в перші 24-48 год і рідше до 72 год. Пізніше використання етіотропної терапії закономірно ви- являється безуспішним, особливо при швидкоплинному вірусному цитопатичному ефекті. Дійсно, коли вірус вже реалізував свій цитопатичний ефект, особливо при масивному ураженні чутливих клітин і запустив бурхливі імунопатологічні реакції, в нашому випадку швидко прогресуючий інтерстиційно-альвеолярний набряк легень, - навіть найактивніші противірусні препарати будуть безсилі. Патологічний процес вже не залежить від реплікації вірусу, оскільки збудник встиг створити нову свою генерацію і на перший план виступають патоморфологічні та імунопатологічні процеси, запущені вірусом.

Відомо, що при SARS і MERS збудники спричиняють активний синтез нейтралізувальних антитіл проти епітопів вірусів, розташованих на S-, M-, N- і HE-антигенах. Найефективніші віруснейтралізувальні антитіла синтезуються у хворих на коронавірусні інфекції до S- і HEантигенів вірусів, меншу активність мають антитіла до M- і N-білків вірусів. Але в комплексі їх сумарна активність істотно підвищується (особливо при імунізації S-, M-, N- і НЕ-антигенами коронавірусів).

У китайських інформаційних джерелах недавно були наведені дані про ефективність використання в терапії COVID-19 плазм і сироваток від тих, хто переніс інорекцію і видужав від неї. Проте, нині немає достовірних даних, які б підтверджували це. Зазначимо, що й раніше при використанні специфрічних антитіл (сироваток, плазми, препаратів імуноглобуліну, що містять ці антитіла у високих титрах) відносно збудників SARS-CoV-1 і MERSCoV у терапії хворих на SARS і MERS були отримані суперечливі дані. Проте при COVID-19 ефективність застосування в етіотропній терапії специфічних віруснейтралізувальних антитіл детального не вивчалася. Тому, маючи так багато одужавжих від COVID-19 (велике число імунних до COVID-19 донорів), вже з активним противірусним імунітетом, все ж потрібне активне дослідження їх віруснейтралізувальних антитіл для лікування і профрілактики COVID-19. Необхідність негайного проведення таких досліджень диктується тим, що, за даними китайських джерел, імунітет до COVID-19, на жаль, може бути нестійким (відомі повторні випадки інфікування). Також можливе створення біотехнологічних моделей для активного синтезу моноклональних вірусоспецифічних нейтралізувальних антитіл.

Цілком очевидно, що, як і при грипі, в разі небезпеки розвитку й прогресування ГРДС, акцент в лікуванні таких хворих слід змістити з етіотропної в бік патогенетичної терапії. Так, наразі обмежене використання на практиці в терапії COVID-19 інгібіторів рецепторів інтерлейкіну-6, які активно використовують у терапії автоімунного ревматоїдного артриту, - сарилумаб (Kevzara) i тоцилізумаб (Actemra), показало їх значну ефективність. Тож отримані емпіричним шляхом дані підтверджують 


\section{ОГЛЯДИ ТА ЛЕКЦІї}

те, що в патогенезі COVID-19 одну з провідних ролей відіграє висока активність імунозапального процесу, у тому числі й автоімунного.

Виходячи із досвіду ефективного застосування глюкокортикоїдів при грипозному геморагічному набряку легень у патогенетичній терапії тяжких фрорм COVID-19, необхідно рекомендувати застосування у таких хворих системних глюкокортикоїдів і, передусім, дексаметазону [5-8].

Дійсно ряд інформаційних джерел в Китаї, всупереч існуючим рекомендаціям американських і європейських медиків, підтверджує ефективність глюкокортикоїдів у терапії COVID-19, щоправда рекомендують використання гідрокортизону.

Зважаючи на особливий ризик розвитку тромбоемболічних ускладнень при COVID-19, передусім високу частоту тромбозів глибоких вен і тромбемболії легеневої артерії, таким пацієнтам необхідно відстежувати рівень D-димеру, несприятливий прогностичний рівень якого становить більше 150 нг/мл. За таких обставин необхідно негайно вдаватися до призначення антикоагулянтної терапії препаратами низькомолекулярних гепаринів, наприклад, еноксипарином 3 розрахунку 1 мг/кг маси тіла на добу.

У багатьох клінічних дослідженнях хворих на пневмонію COVID-19 обнадійливі результати показує застосування оксиду азоту - селективного легеневого вазодилататора, що знижує опір легеневих судин, покращуючи відповідність вентиляції та перфузії тканини легень.

3 огляду на згадану тропність SARS-CoV-2 до ендотелію капілярів, значне місце у лікуванні може зайняти використання ангіо- і кардіопротекторних засобів. Зокрема багатообіцяючими видаються вітчизняні препарати кверцетину - квертин і корвітин.

Відомо, що кверцетин є пасткою для вільних радикалів і має здатність активувати фрерменти власного антиоксидантного захисту організму. Він чинить протизапальну дію, що зумовлено блокадою ліпооксигеназного шляху метаболізму арахідонової кислоти, зниженням синтезу лейкотрієнів, серотоніну та інших медіаторів запалення [9].

Вагомий інтерес становить захисний вплив кверцетину стосовно дихальної системи, особливо легеневої тканини. У дослідженні Р. Kumar та співавторів (2005) кверцетин відновлював концентрацію багатьох антиоксидантів (каталази, глутатіондисмутази, супероксиддисмутази) у легенях лабораторних гризунів, заражених вірусом грипу А [10].

Інтерес до кверцетину як засобу профрілактики та лікування COVID-19 при високій гостроті цієї проблеми на сьогодні знайшов свій відгук у багатьох фахівців наукового та лікувального профрілю. Зокрема, у протоколі
(EVMS Medical Group) ведення пацієнтів із COVID-19 3 метою зниження тяжкості захворювання в особливо вразливих осіб (віком більше 60 років), а також для пацієнтів із легкою симптоматикою рекомендується застосовувати комбінацію кверцетину та вітаміну C по 250-500 мг двічі на добу. Таке лікування знижувало ризик пошкодження клітин, а також зменшувало вміст маркерів запалення [11, 12].

Застосування кверцетину в лікуванні хворих на COVID-19 планується також у дослідженні канадських вчених M. Chretien та M. Mbikay, які мають досить великий досвід досліджень впливу кверцетину при гострих респіраторних інфекціях на тваринних моделях. При цьому, за розробленим протоколом, планується застосовувати кверцетин у дозі 500 мг протягом усього лікувального процесу за участю близько 1000 хворих. Управління із санітарного нагляду за якістю харчових продуктів і медикаментів США (Food and Drug Administration - FDA) затвердило кверцетин як безпечну для споживання людиною речовину, тому стає непотрібним тестування його безпеки на тваринах. Отже, кверцетин $€$ доступною для лікування речовиною, яку можна швидко долучити до терапевтичного процесу. Передбачається, що застосування кверцетину в лікуванні хворих на COVID-19 матиме вагомі фрармакоекономічні переваги, оскільки вартість досліджуваного лікування становитиме всього 2 дол. США на добу на одного пацієнта [13].

3 огляду на ускладнення 3 боку серцево-судинної системи, спричинені впливом як самого коронавірусу, так і препаратів, які застосовують при лікуванні COVID-19 [14-16], актуальними є дані про кардіопротекторний вплив кверцетину, отримані у ряді доклінічних досліджень. Кардіопротекторна дія кверцетину проявляється багатьма позитивними ефектами, серед яких особливо значними є обмеження зони некрозу міокарда, запобігання його реперфузійному ураженню; а також антиаритмічна, антиішемічна, антитромботична дія, встановлені при лікуванні гострого коронарного синдрому, гострого інфраркту міокарда та гострої серцевої недостатності [17]. Встановлено також його захисний вплив на ендотелій судин, що має вагоме значення при COVID-19, оскільки при цій патології неминуче розвивається ендотеліальна дисорнкція [18].

Окремим важливим питанням $є$ призначення антибіотиків при COVID-19. Не підлягає сумніву, що антибактерійна терапія усіх таких пацієнтів неприпустима, навіть, зважаючи на «профрілактичну» мету зазначеного лікування. Дуже чітким об'єктивним критерієм на користь антибіотикотерапії $€$ рівень прокальцитоніну більше 0,02 нг/мл. За таких обставин перевага надається антибіотикам широкого спектру дії. 
Насамкінець зазначимо, що, незважаючи на існуючий досвід боротьби з широкомасштабними епідеміями SARS i MERS, ми не зробили вагомих висновків. Після фактично самолімітації SARS і MERS реальні наукові й практичні дослідження в галузі етіотропної терапії та, найголовніше, специфрічної профрілактики цих коронавірусних інфекцій були згорнуті. Як наслідок, через майже 18 років не розроблено ні реальної етіотропної терапії, ані специорічної імунопрофрілактики стосовно SARS і MERS. Ми виявилися не готовими і до пандемії COVID-19.

Не враховуючи застосовувані протиепідемічні заходи, досі немає етіотропних противірусних препаратів, вакцин, специфічного гіперімунного анти-SARS-CoV-2 гамма- чи імуноглобуліну або специфрічних віруснейтралізувальних сироваток, які можна було б застосовувати з метою профрілактики COVID-19.

Але вихід усе ж $є$. Попри те, що коронавіруси активно пригнічують інтерферонову систему людини, іїі активація і локальне введення інтерферонів з профрілактичною метою не лише можливе, але й необхідне. Це не забезпечить 100 \% гарантії, але усе ж дасть шанс на індивідуальний неспецифрічний захист.

Як засоби індивідуального захисту можна використовувати вже готові інтерферони або системно застосовувати індуктори інтерсрероногенезу. Так, готові препарати (зрозуміло, за відсутності протипоказань) доцільно використовувати у вигляді інтраназальних інсталяцій (у вигляді спрею 3 активністю інтерферону не менше 100000 МО/мл). На жаль, на сьогодні доступні тільки а-ІФН. Для системної активації (також за відсутності протипоказань) можна використовувати індуктори системи інтерсрерону. Досвід їх застосування показує, що зараз найбільш ефективними виявилися синтетичні сполуки - фрлуоренони і акриданони (циклоферон, неовір та ін.). Але спектр індукторів інтерсрероногенезу дуже багатий. Так, до синтетичних препаратів належать полімери: полудан, ампліген, поліагуцил; до природних (низькомолекулярні поліфеноли): похідні госиполу - мегасин, кагоцел, саврац рогасин, гозалідон; і полімери (двоспіральні РНК) - ларифран, ридостин.

Індуктори інтерорероногенезу мають суттєві переваги перед інтерфероном, оскільки зазвичай позбавлені високого ступеня антигенності (рідко спричиняють алергічні реакції); активують синтез усіх класів інтерферону ( $\alpha$ і y), не здатні зумовлювати синтез украй високих рівнів інтерферону, але можуть забезпечити тривалий їх рівень у крові й тканинах людини, в основному добре поєднуються з іншими фрармакологічними препаратами. Як індуктор інтерфероногенезу можна використовувати доступний і давно відомий бендазол (дибазол).
Підбиваючи підсумок, необхідно зазначити, що, незважаючи на існуючу сьогодні потужну лабораторну молекулярно-діагностичну базу, повну розшифровку геному SARS-CoV-2, використання потужних комп'ютерів для моделювання і підбору препаратів, терапія хворих на COVID-19 ще дуже далека навіть від етапу реальних клінічних випробувань. Як і раніше, незважаючи на найпотужніші світові наукові, науково-технічні та біотехнологічні виробничі бази, сьогодні, як і багато десятиліть тому, доводиться задовольнятися фрактично методом емпіричного підбору фрармакологічних кандидатів на роль патогенетичних і противірусних засобів при COVID-19.

Не більш дослідженою залишається і медикаментозна профрілактика цієї хвороби. Сьогодні тестується чимало вакцин, однак, попри бадьорі запевнення виробників, результати їх випробувань поки що не можна назвати задовільними. На заваді реальному прориву у цій справі стоїть не тільки мутація вірусу, але й відомий імунний френомен антитілозалежного посилення інфекції (antibody-dependent enhancement - ADE), що розвивається у відповідь на білок S коронавірусу [19]. Він полягає в посиленні іноекційного процесу специфічними до збудника інфекційної хвороби антитілами. Такі антитіла утворюють комплекси зі збудником інфекційної хвороби за допомогою Fc-фррагменту антитіла і взаємодіють або зі специфрічним до Fc-фррагменту рецептором (Fcreceptor - FcR), або з рецептором комплементу (complement receptor - CR) на поверхні фрагоцитувальних клітин. Відбувається не лише посилення інфекційного процесу в результаті розмноження мікроорганізму у фрагоцитах, але й зміна тропності коронавірусу. SARSCoV на початковій стадії інфекційного процесу не інфрікує моноцити/макрофраги, зв'язуючись із рецептором ACE2 в нижніх відділах легень [20]. Але антитіла до шипа (білок S) оболонки SARS-CoV, що поступово виробляються імунною системою людини у відповідь на інфекцію, сприяють проникненню SARS-CoV у моноцити і макрофаги через FcyRIIA-рецептор і призводять то тяжчого ступеня хвороби [21].

Феномен ADE виявлений M.S. Үір зі співавт. [22] через 8 років після ідентиорікації SARS-CoV у 2003 р., коли дослідження зі створення SARSCoV-вакцин вже звелися до демонстрації «принципової можливості» їх створення. ще через рік М. Јaume зі співавт. [23] продемонстрували, що «не нейтралізувальні антитіла» (nonneutralizing antibodies, як їх тоді делікатно називали), які індукуються повнорозмірним S-білком SARS-CoV, у низьких концентраціях полегшують проникнення вірусу в клітини через FcyR-залежний шлях. Стало зрозуміло, чому спішно створені у 2004-2005 рр. на основі повнорозмірного S-білка кандидатні вакцини проти SARS-CoV 
індукували вироблення антитіл, які не запобігали зараженню цим вірусом експериментальних тварин. Навпаки, вони викликали у них розвиток гепатиту і робили інфекційний процес тяжчим [19, 24]. У зв'язку з цим подальші роботи зі створення таких вакцин були згорнуті.

Таким чином, френомен ADE є критичною проблемою при розробці CoV-вакцин, у тому числі й проти SARSCoV-2. В умовах експерименту шляхом оптимально підібраної схеми вакцинації та в контрольованих умовах можна досягти на короткий час протективного ефекту навіть такими антитілами, якщо їх концентрація в сироватці крові дозволить блокувати більшість спайк-білків CoV. Проте з часом, при падінні концентрації антитіл до субнейтралізувальних, неминуче проявить себе ADE. I ті залишкові кількості антитіл до епітопів білка S, які будуть у сироватці крові упродовж десятиліть, стануть свого роду тригером, що запускає тяжкий інорекційний процес при повторному контакті імунної системи людини $з$ коронавірусом.

Поки верстався номер, у мережі Інтернет з'явилося повідомлення під сенсаційною назвою «У Великобританії заявили про прорив у лікуванні COVID-19», в якому зазначається, що «британські науковці, які працюють над пошуками ліків від хвороби COVID-19, викликаної новим коронавірусом, заявили у вівторок,
16 червня, про «великий прорив» у своїх дослідженнях під час роботи зі стероїдом під назвою «дексамета3ОН».

Так, дослідження, участь у якому взяли 2104 пацієнти, показало, що вживання дексаметазону у невеликих дозах на третину зменшило кількість смертей серед тих, хто був підключений до апаратів штучної вентиляції легенів. І вп'ятеро зменшило кількість померлих серед пацієнтів, які використовували кисневі маски. Ці результати дослідники назвали «великим проривом», який «врятує життя».

За словами Мартіна Ландрей з Оксфордського університету, одного з керівників дослідження, дексаметазон може виявитися «напрочуд дешевим» засобом боротьби з пандемією коронавірусу, передає агенція dpa.

Його колега, профресор Пітер Хорбі заявив, що дексаметазон це - «перші ліки, що продемонстрували поліпшення показників виживаності при COVID-19»» [25].

Нарешті 25 червня 2020 р. і Міністерство охорони здоров'я України, прислухавшись до здорового глузду й діаметрально заперечивши своє попереднє розпорядження, включило у «Протокол» необхідність застосування при COVID-19 дексаметазону [26].

\section{Література}

1. Epidemiological and clinical characteristics of 99 cases of 2019 novel coronavirus pneumonia in Wuhan, China: a descriptive study / N. Chen, M. Zhou, X. Dong [et al.] // The Lancet. - 2020. - Vol. 395. - P. 507-513. www.thelancet.com Published online January 29, 2020 https://doi.org/10.1016/S0140-6736(20)30211-7

2. Новый коронавирус, вызывающий заболевание человека / Л.Ф. Стовба, В.Н. Лебедев, А.А. Петров [и др.] // Проблемы особо опасных инфекций. - 2015. - Вып. 2. - С. 68-74.

3. Gralinski L. E. Molecular pathology of emerging coronavirus infections / L. E. Gralinski, R. S. Baric // J. Pathol. - 2015. - Vol. 235. - P. 185-195. - Access mode : https://doi.org/ 10.1002/path.4454

4. Pulmonary pathology of early-phase 2019 novel coronavirus (COVID-19) pneumonia in two patients with lung cancer / S. Tian, W. Hu, L. Niu [et al.] // J. Thorac. Oncol. - 2020. - N 20. - P. 30132-30135.

5. Бондаренко А.М. Грип A/H1N1 - реалії та особливості / А.М. Бондаренко // Інфеекційні хвороби. - 2009. - № 4. - С. 96-102.

6. Копча В.С. Грипп: пневмония или отёк легких? Особенности патогенеза и лечения / В.С. Копча, А.Н. Бондаренко // Здравоохранение Белоруссии. - 2011. - № 2. - С. 44-49.

7. Патент 63098. Україна, МПК А61К 31/573 (2006.01). Спосіб лікування грипозного геморагічного набряку легень / А.М. Бондаренко, М.А. Андрейчин, В.С. Копча. - № и 2011 02908; Заявлено 12.03.2011; Опубл. 26.09.2011, Бюл. № 18.

8. Копча В.С. Патогенетичне обґрунтування лікування хворих на грип та інші ГРВІ / В.С. Копча, Ю.В. Копча // Інфекційні хвороби - 2014. - № 4(78). - C. 64-70.
9. Перспективи вивчення застосування препаратів кверцетину в лікуванні COVID-19 / I.A. Зупанець, О.А. Голубовська, А.В. Шкурба [та ін.] // Укр. мед. часопис. - 2020. - № 2(1). E-resources: https://www.umj.com.ua/article/177136/perspektivi-vivchennyazastosuvannya-preparativ-kvertsetinu-v-likuvanni-covid-19

10. Effect of quercetin supplementation on lung antioxidants after experimental influenza virus infection / P. Kumar, M. Khanna, V. Srivastava [et al.] // Exp. Lung. Res. - 2005. - Vol. 31 (5). - P. 449459.

11. Marik P. EVMS critical care COVID-19 management protocol / P. Marik. - 2020. - Access mode : https://www.evms.edu/media/ evms_public/departments/internal_medicine/EVMS_Critical_Care_ COVID-19_Protocol.pdf.

12. The effect of quercetin supplementation on selected markers of inflammation and oxidative stress / G. Askari, R. Ghiasvand, A. Feizi [et al.] // J. Res. Med. Sci. - 2012. - Vol. 6. - P. 637-641.

13. A made-in-Canada solution to the coronavirus outbreak? / N. Taylor-Vaisey. - 2020. - Access mode : https://www.macleans.ca/ news/canada/a-made-in-canada-solution-to-the-coronavirus-outbreak/

14. Coronavirus as a possible cause of severe acute respiratory syndrome / J.S. Peiris, S.T. Lai, L.L. Poon [et al.] // Lancet. - 2003. Vol. 361. - P. 1319-1325.

15. Handbook of COVID-19. Prevention and treatment / Liang T. (Ed.). - Zhejiang University School of Medicine, 2020. - 60 p.

16. Traditional chinese medicine in the treatment of patients infected with 2019-new coronavirus (SARS-CoV-2): a review and 
perspective / Y. Yang, M. S. Islam, J. Wang [et al.] // Int. J. Biol. Sci. 2020. - Vol. 16 (10). - P. 1708-1717.

17. Endothelial cell infection and endotheliitis in COVID-19 / Z. Varga, A. J. Flammer, P. Steiger [et al.] // Lancet. - 2020. - Vol. 395 (10234). - P. 1417-1418. DOI: 10.1016/S0140-6736(20)30937-5.

18. Лук'янчук В.Д. Кінетика вільнорадикальних реакцій у щурів 3 медикаментозним гепатитом при застосуванні таблеток «Кверцетин» / В.Д. Лук'янчук, А.Г. Войтенко // Фармакологія та лікарська токсикологія. - 2008. - № 1-3. - С. 52-57.

19. Супотницкий М.B. Новый коронавирус SARS-CoV-2 в аспекте глобальной эпидемиологии коронавирусных инфекций / М.В. Супотницкий // Вестник войск РХБ защиты. - 2020. - Т. 4, № 1. - C. 32-65.

20. SARS-like cluster of circulating bat coronavirus pose threat for human emergence / V. D. Menachery, B. L. Yount, K. Debbink [et al.] // Nat. Med. - 2015. - Vol. 21, N 12. - P. 1508-1513. - Access mode : https://doi.org/ 10.1038/nm.3985/

21. Antibody-dependent infection of human macrophages by severe acute respiratory syndrome coronavirus / M. S. Yip, N. H. L. Leung,

\section{References}

1. Chen, N., Zhou, M., Dong, X., Qu, J., Gong, F., \& Han, Y. (2020). Epidemiological and clinical characteristics of 99 cases of 2019 novel coronavirus pneumonia in Wuhan, China: a descriptive study. The Lancet, 395: 507-513. www.thelancet.com https://doi.org/10.1016/ S0140-6736(20)30211-7

2. Stovba, L.F., Lebedev, V.N., Petrov, A.A., Ruchko, V.M., Kulish, V.S., Borisevich, S.V. (2015). A new coronavirus that causes human disease. Problemy osobo opasnykh infektsiy - Problems of Extrahazardous Infections, 2, 68-74 [in Russian].

3. Gralinski, L.E., \& Baric, R.S. (2015). Molecular pathology of emerging coronavirus infections. J. Pathol., 235, 185-195. Retrieved from: https://doi.org/ 10.1002/path.4454

4. Tian, S., Hu, W., Niu, L., Liu, H., Xu, H., \& Xiao, S.Y. (2020). Pulmonary pathology of early-phase 2019 novel coronavirus (COVID-19) pneumonia in two patients with lung cancer. J. Thorac. Oncol., 20, 30132-30135.

5. Bondarenko, A.M. (2009). Influenza A / H1N1 - realities and features. Infektsiini khvoroby - Infectious Diseases, 4, 96-102 [in Ukrainian].

6. Kopcha, V.S., \& Bondarenko, A.N. (2011). Influenza: pneumonia or pulmonary edema? Features of pathogenesis and treatment. Zdravookhraneniye Belorussii - Health Protection of Belorussia, 2, 44-49 [in Russian].

7. Bondarenko, A.M., Andreychyn, M.A., \& Kopcha, V.S. (2011). Patent 63098. Ukraine, IPC A61K 31/573 (2006.01). A method of treating influenza hemorrhagic pulmonary edema. Bulletin, 18 [in Ukrainian].

8. Kopcha, V.S., \& Kopcha, Yu.V. (2014). Pathogenetic substantiation of treatment of patients with influenza and other ARVI. Infektsiini khvoroby - Infectious Diseases, 4 (78), 64-70 [in Ukrainian].

9. Zupanets, I.A., Holubovska, O.A., Shkurba, A.V., Shebeko, S., \& Shalamay, A.S. (2020). Prospects for studying the use of quercetin drugs in the treatment of COVID-19. Ukrainskyi medychnyi chasopys Ukrainian Medical Herald, 2 (1). Retrieved from: https://www.umj.com. ua/article/177136/perspektivi-vivchennya-zastosuvannya-preparativkvertsetinu-v-likuvanni-covid-19 [in Ukrainian].
C. Y. Cheung [et al.] // Virol. J. - 2014. - Vol. 11. - P. 82. - Access mode : https://doi.org/10.1186/1743-422X-11-82

22. Investigation of antibody-dependent enhancement (ADE) of SARS coronavirus infection and its role in pathogenesis of SARS / M. S. Yip, C. Y. Cheung, P. H. Li [et al.] // BMC Proc. - 2011. - Vol. 5 (Suppl. 1). - P. 80.

23. SARS CoV subunit vaccine: antibody-mediated neutralisation and enhancement / M. Jaume, M. S. Yip, Y. W. Kam [et al.] // Hong Kong Med. J. - 2012. - Vol. 18 (Suppl. 2). - P. 31-36.

24. Antibodydependent SARS coronavirus infection is mediated by antibodies against spike proteins / S. F. Wang, S. P. Tseng, C. H. Yen [et al.] // Biochem. Biophys. Res. Commun. - 2014. - Vol. 451. P. 208-214. -Access mode : https://doi.org/10.1016/j.bbrc.2014.07.090

25. DW. Made for minds. У Великобританії заявили про прорив у лікуванні COVID-19. - 16.06.2020. - Acces mode : https://www. dw.com/uk/u-velykobrytanii-zaiavyly-pro-proryv-u-likuvanni-covid-19/a53830442? maca=ukr-rss-ukrnet-ukr-all-3816-xml

26. МОЗ внесло до протоколу лікування COVID-19 дексаметазон. - 25.06.2020. E-resources: https://prm.ua/moz-vneslo-doprotokolu-likuvannya-covid-19-deksametazon/
10. Kumar, P., Khanna, M., Srivastava, V., Tyagi, Y.K., Raj, H.G., \& Ravi, K. (2005). Effect of quercetin supplementation on lung antioxidants after experimental influenza virus infection. Exp. Lung. Res., 31 (5), 449-459.

11. Marik, P. (2020). EVMS critical care COVID-19 management protocol. Retrieved from: https://www.evms.edu/media/evms public/ departments/internal_medicine/EVMS_Critical_Care_COVID-19_ Protocol.pdf.

12. Askari, G., Ghiasvand, R., Feizi, A., Ghanadian, S. M., \& Karimian, J. (2012). The effect of quercetin supplementation on selected markers of inflammation and oxidative stress. J. Res. Med. Sci., 6: 637-641.

13. Taylor-Vaisey, N. (2020). A made-in-Canada solution to the coronavirus outbreak? Retrieved from: https://www.macleans.ca/ news/canada/a-made-in-canada-solution-to-the-coronavirus-outbreak/

14. Peiris, J. S. M., Lai, S. T., Poon, L. L. M., Guan, Y., Yam, L. Y. C., Lim, W., ... \& Cheng, V. C. C. (2003). Coronavirus as a possible cause of severe acute respiratory syndrome. The Lancet, 361 (9366), 13191325.

15. Liang, T. (2020). Handbook of COVID-19. Prevention and Treatment. Zhejiang University School of Medicine.

16. Yang, Y., Islam, M. S., Wang, J., Li, Y., \& Chen, X. (2020). Traditional Chinese medicine in the treatment of patients infected with 2019-new coronavirus (SARS-CoV-2): a review and perspective. International Journal of Biological Sciences, 16 (10), 1708.

17. Varga, Z., Flammer, A.J., Steiger, P., Haberecker, M., Andermatt, R., Zinkernagel, A.S., ... \& Moch, H. (2020). Endothelial cell infection and endotheliitis in COVID-19. The Lancet, 395 (10234), 1417-1418. DOI: 10.1016/S0140-6736(20)30937-5.

18. Lukanchuk, V.D., \& Voytenko, A.H. (2008). Kinetics of free radical reactions in rats with drug-induced hepatitis when using Quercetin tablets. Farmakolohiia ta likarska toksykolohiia Pharmacology and Medical Toxicology, 1-3, $52-57$ [in Ukrainian].

19. Supotnitskiy, M.V. (2020). New coronavirus SARS-CoV-2 in the aspect of the global epidemiology of coronavirus infections. 


\section{ОГЛЯДИ ТА ЛЕКЦІї}

Vestnik voysk RKHB zashchity - Journal of NBC Protection Corps, 4 (1), 32-65 [in Russian].

20. Menachery, V. D., Yount Jr, B. L., Debbink, K., Agnihothram, S., Gralinski, L.E., Plante, J.A., ... \& Randell, S.H. (2015). A SARSlike cluster of circulating bat coronaviruses shows potential for human emergence. Nature Medicine, 21 (12), 1508-1513. Retrieved from: https://doi.org/ 10.1038/nm.3985/

21. Yip, M.S., Leung, N.H.L., Cheung, C.Y., Li, P.H., Lee, H.H.Y., Daëron, M., ... \& Jaume, M. (2014). Antibody-dependent infection of human macrophages by severe acute respiratory syndrome coronavirus. Virology Journal, 11, 82. Retrieved from: https://doi. org/10.1186/1743-422X-11-82

22. Yip, M. S., Cheung, C. Y., Li, P. H., Bruzzone, R., Peiris, J. M., \& Jaume, M. (2011, December). Investigation of Antibody-Dependent Enhancement (ADE) of SARS coronavirus infection and its role in pathogenesis of SARS. In BMC proceedings (Vol. 5, No. S1, p. P80). BioMed Central.

\section{REFLECTIONS ON THE TREATMENT AND PREVENTIVE PROSPECTIVITY OF VARIOUS AGENTS AT COVID-19}

\footnotetext{
A.M. Bondarenko ${ }^{1}$, V.S. Kopcha ${ }^{2}$

${ }^{1}$ Clinical Hospital N 2 of Kryvyi Rih, Center of Health of Kryvyi Rih 2. Horbachevsky Ternopil National Medical University

SUMMARY. The aim of the work is to identify promising areas of further therapy and prevention on the basis of comparing the features of previous epidemics of coronavirus infections and analysis of pathohistology, pathogenesis of COVID-19 and the experience of empirically approved treatment of such patients.

Information over is brought about reverse dependence in a number of SARS $\rightarrow$ MERS $\rightarrow$ COVID-19 geographical prevalence with a latent period and lethality.

In pathogenesis of COVID-19 two basic nosotropic mechanisms are distinguished: direct viral damage of epithelium of lungs, endotheliocytes of capillaries and tissue pulmonary desmocytes, and also making progress used for setting fire reaction, which is accompanied by a "cytokine storm" which at first can result in an "acute respiratory distress syndrome", and then - to the socalled syndrome of the abrupt used for setting fire reply. Thus, pathogenesis of COVID-19 alike with influenzal "hemorragic pneumonias" or influenzal hemorragic pulmonary edema. It enables to assume the primary value of not ethiotropic, but nosotropic antioedematous, antiinflammatory and angioprotective therapies of patients with COVID-19.

Perspective prophylactic concerning COVID-19 agents are seemed by the prepared interferons or inductors of interferonogenesis.
}

23. Jaume, M., Yip, M. S., Kam, Y. W., Cheung, C. Y., Kien, F., Roberts, A., ... \& Bruzzone, R. (2012). SARS CoV subunit vaccine: antibodymediated neutralisation and enhancement. Hong Kong Med. J., 18 (2), 31-36.

24. Wang, S. F., Tseng, S. P., Yen, C. H., Yang, J. Y., Tsao, C. H., Shen, C. W., ... \& Huang, J. C. (2014). Antibody-dependent SARS coronavirus infection is mediated by antibodies against spike proteins. Biochemical and Biophysical Research Communications, 451, 208214. Retrieved from: https://doi.org/10.1016/j.bbrc.2014.07.090

25. DW. Made for minds (16.06.2020). In Great Britain declared about a breach in treatment of COVID-19. Retrieved from: https://www. dw.com/uk/u-velykobrytanii-zaiavyly-pro-proryv-u-likuvanni-covid19/a-53830442?maca=ukr-rss-ukrnet-ukr-all-3816-xml [in Ukrainian].

26. MHU (25.06.2020). Ministry of health of Ukraine entered Dexamethazonum in the minutes of COVID-19 treatment. Retrieved from: https://prm.ua/moz-vneslo-do-protokolu-likuvannya-covid-19deksametazon/ [in Ukrainian].

Key words: COVID-19; epidemiology; pathohistology; pathogenesis; treatment; prophylaxis.

\section{Відомості про авторів:}

Бондаренко Анатолій Миколайович - д. мед. н., завідувач кафедри екології Криворізького національного університету; керівник Центру діагностики та лікування інфекційних хвороб, м. Кривий Ріг; e-mail: kryobon@ukr.net

Копча Василь Степанович - д. мед. н., профресор кафредри інфеекційних хвороб з епідеміологією, шкірними і венеричними хворобами Тернопільського національного медичного університету імені І.Я. Горбачевського; e-mail: kopcha@ukr.net

ORCID: https://orcid.org/0000-0001-9499-3733

\section{Information about the authors:}

Bondarenko A.M. - MD, Head of the Department of Ecology, Kryvyi Rih National University; Head of the Center for the Diagnosis and Treatment of Infectious Diseases, Kryvyi Rih; e-mail: kryobon@ukr.net

Kopcha V.S. - MD, Professor of the Infectious Diseases and Epidemiology, Skin and Venereal Diseases Department I. Horbachevsky Ternopil National Medical University; e-mail: kopcha@ukr.net

ORCID: https://orcid.org/0000-0001-9499-3733

Конорлікт інтересів: немає.

Authors have no conflict of interest to declare.

Отримано 11.05.2020 р. 